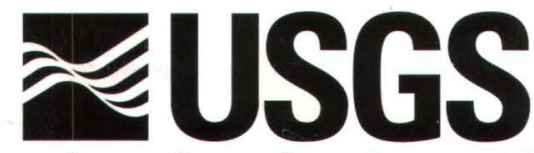

\title{
Assessment of Environmental Factors Affecting Fecal-Coliform Concentrations in Hampton/Seabrook Harbor, New Hampshire, 2000-01
}

Water-Resources Investigations Report 02-4252

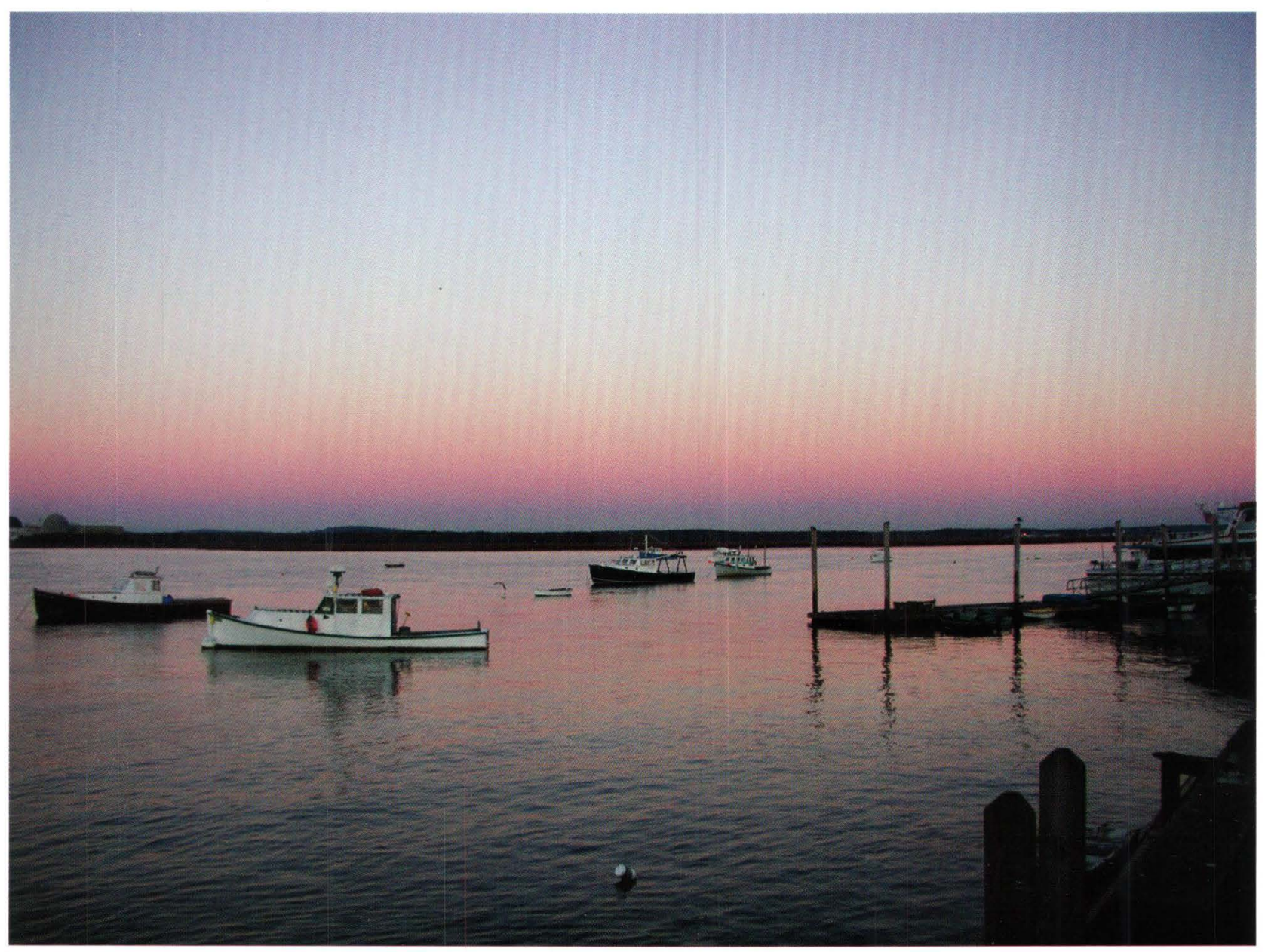


Cover photograph shows Hampton/Seabrook Harbor, New Hampshire, at sunrise. (Photograph by W. Christopher Nash, New Hampshire Department of Environmental Services) 


\section{Assessment of Environmental Factors Affecting Fecal-Coliform Concentrations in Hampton/Seabrook Harbor, New Hampshire, 2000-01}

By Jeffrey R. Deacon and W. Christopher Nash

Water-Resources Investigations Report 02-4252

In cooperation with the

NEW HAMPSHIRE DEPARTMENT OF ENVIRONMENTAL SERVICES 


\title{
U.S. DEPARTMENT OF THE INTERIOR GALE A. NORTON, Secretary
}

\author{
U.S. GEOLOGICAL SURVEY \\ CHARLES G. GROAT, Director
}

The use of firm, trade, and brand names in this report is for identification purposes only and does not constitute endorsement by the U.S. Government.

For additional information write to:

District Chief

U.S. Geological Survey

New Hampshire/Vermont District

361 Commerce Way

Pembroke, NH 03275-3718

or through our Web site at

http://nh.water.usgs.gov

Copies of this report can be purchased from:

U.S. Geological Survey

Branch of Information Services

Box 25286

Federal Center

Denver, CO 80225-0286 


\section{CONTENTS}

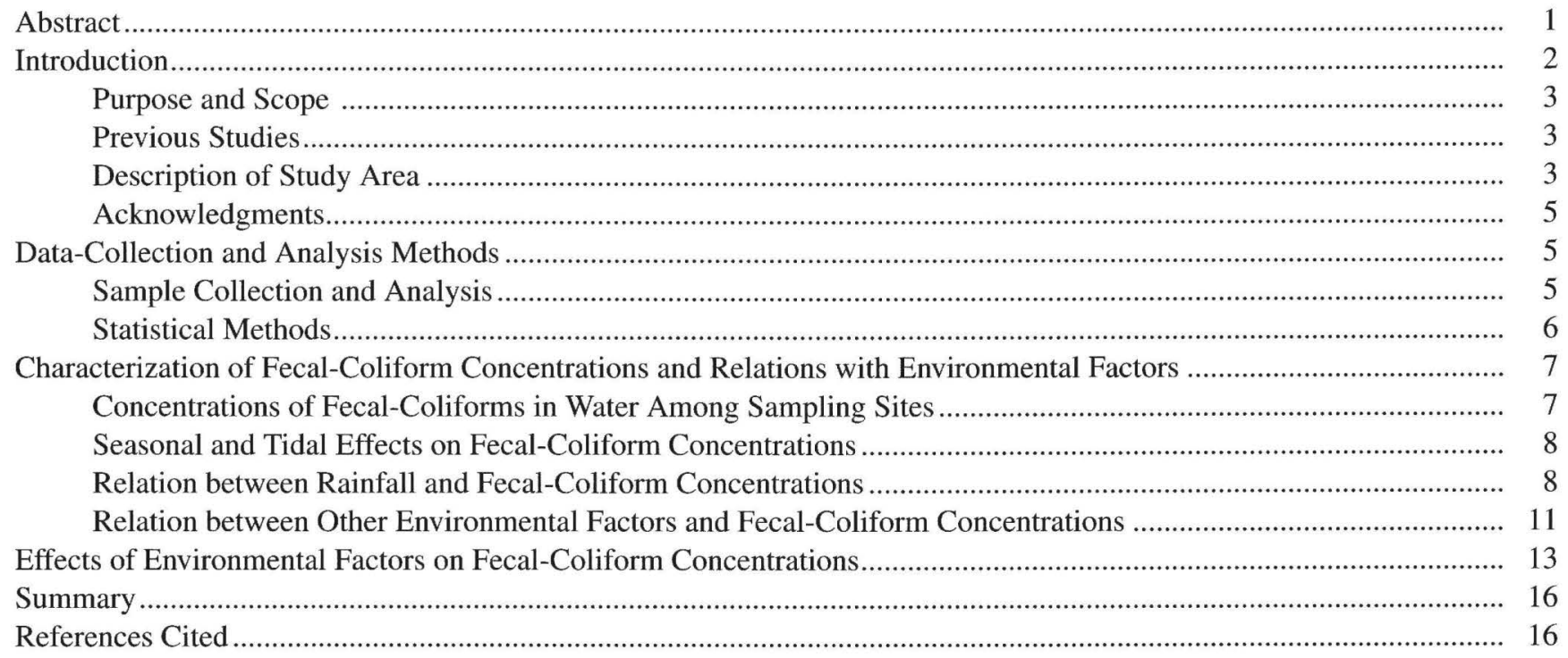

\section{FIGURES}

1. Map showing Hampton/Seabrook Harbor and tributaries, and sampling sites, southeastern New Hampshire.

2-7. Boxplots showing range of:

2. Fecal-coliform concentrations by season at Hampton/Seabrook Harbor, New Hampshire

3. Fecal-coliform concentrations for historical (1988-99) and current (2000-01) data in relation to season ....... 9

4. Fecal-coliform concentrations by tide cycle at sampling sites................................................................. 10

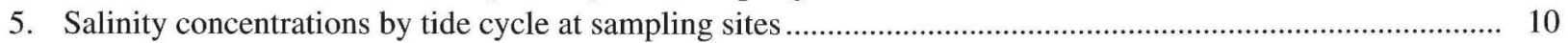

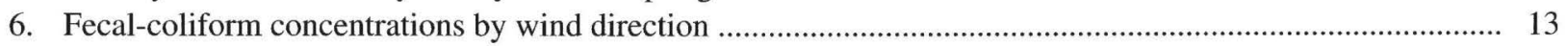

7. Fecal-coliform concentrations by wind speed...................................................................................... 14

\section{TABLES}

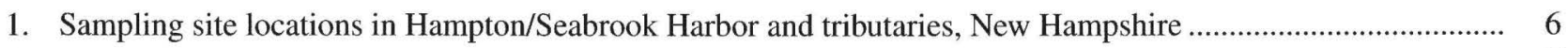

2. Summary statistics for fecal-coliform concentrations at sampling sites ............................................................ 7

3. Median and geometric-mean concentrations of fecal coliform by rainfall category ........................................... 8

4. Summary of correlations between fecal-coliform concentrations, rainfall variables, and

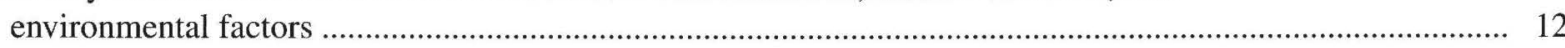

5. Regression statistics for $\log _{10}$ fecal-coliform concentrations and rainfall variables for samples collected during the spring and fall 
CONVERSION FACTORS AND ABBREVIATIONS

\begin{tabular}{rll}
\hline Multiply & \multicolumn{1}{c}{ By } & To obtain \\
\hline foot $(\mathrm{ft})$ & 0.3048 & meter $(\mathrm{m})$ \\
mile $(\mathrm{mi})$ & 1.609 & kilometer $(\mathrm{km})$ \\
square mile $\left(\mathrm{mi}^{2}\right)$ & 2.590 & square kilometer $\left(\mathrm{km}^{2}\right)$ \\
cubic inch $\left(\mathrm{in}^{3}\right)$ & 0.06102 & milliliter $(\mathrm{mL})$ \\
miles per hour $(\mathrm{mph})$ & 1.609 & kilometers per hour $(\mathrm{km} / \mathrm{hr})$
\end{tabular}

Temperature in degrees Celsius $\left({ }^{\circ} \mathrm{C}\right)$ can be converted to degrees Fahrenheit $\left({ }^{\circ} \mathrm{F}\right)$ as follows:

$$
{ }^{\circ} \mathrm{F}=1.8\left({ }^{\circ} \mathrm{C}\right)+32
$$

\section{ABBREVIATIONS USED IN THIS REPORT}

Concentrations of fecal coliforms are reported in Most Probable Number (MPN) per 100 milliliter (mL) and in colonies per $100 \mathrm{~mL}$.

Salinity is reported in parts per thousand (ppt).

Turbidity is reported in Nephelometric Turbidity Units (NTUs). 


\title{
Assessment of Environmental Factors Affecting Fecal-Coliform Concentrations in Hampton/Seabrook Harbor, New Hampshire, 2000-01
}

\author{
By Jeffrey R. Deacon and W. Christopher Nash
}

\begin{abstract}
Environmental factors that affect concentrations of fecal-coliform bacteria were investigated by the U.S. Geological Survey, in cooperation with the New Hampshire Department of Environmental Services, at Hampton/Seabrook Harbor in the towns of Hampton, Hampton Falls, and Seabrook, N.H. Hampton/Seabrook Harbor and nearby tributaries constitute one of the most productive shellfish habitats in New Hampshire. Water samples and data on other environmental factors were collected from the Harbor and tributaries on a routine and precipitation-event basis from March 2000 through December 2001. Water samples were analyzed for fecal-coliform concentrations. Data for other environmental factors collected included rainfall, salinity, turbidity, water temperature, wind speed, wind direction, air temperature, qualitative counts on bird populations, and basin characteristics such as area served by municipal sewer, on-site septic systems, and population density. These environmental factors were tested to determine if any relations were present with fecal-coliform concentrations in water.

Statistical tests indicated a significant difference for fecal-coliform concentrations between samples collected in the spring and fall $(\mathrm{p}<0.05)$. Samples collected during neap-tide cycles generally had higher fecal-coliform concentrations than did samples collected during spring-tide cycles. Median fecal-coliform
\end{abstract}

concentrations increased with increasing rainfall, indicating that rainfall can directly affect concentrations of fecal coliforms in the Harbor. The strongest correlations were found between fecalcoliform concentrations and cumulative 4-day and weighted rainfall amounts $(\mathrm{p}<0.05$; rho $=0.45-$ 0.59 ). Correlations were found between fecalcoliform concentrations and turbidity for the spring samples $(\mathrm{p}<0.05$; rho $=0.45)$ but not for fall samples. Correlations between fecal-coliform concentrations and other factors, such as salinity, were weak or not statistically significant.

Simple-linear regression analysis was used to determine if rainfall and other factors, such as salinity and turbidity, could explain some of the variation in fecal-coliform concentrations. When rainfall was used as a single predictor variable, cumulative 4-day and weighted-rainfall data explained more variation in fecal-coliform concentrations $\left(\mathrm{R}^{2}=0.18-0.21\right)$ than did peak or average intensity of the rainfall, 1-day rainfall, 2-day rainfall, and other factors such as salinity and turbidity. The low $\mathrm{R}^{2}$ values indicated other possible factors affect the variation in fecalcoliform concentrations. Multiple-linearregression analysis was used to include a combination of factors that might explain the variation better than simple-linear regression. In this analysis, 2-day (spring) and 4-day (fall) rainfall, water temperature, and turbidity increased the $\mathrm{R}^{2}$ values and improved the strength of the statistical relation $\left(\mathrm{R}^{2}=0.43-0.48\right)$. 


\section{INTRODUCTION}

Hampton/Seabrook Harbor, New Hampshire, referred to as the Harbor in this report, and nearby tributaries are among the most productive shellfish habitats in New Hampshire. The estuary is the most popular location in coastal New Hampshire for the recreational harvesting of softshell clams (Mya arenaria). The New Hampshire Department of Environmental Services (NHDES), Shellfish Program, is responsible for evaluating the sanitary quality of the area for harvesting. Historically, these waters have been closed to harvesting because of fecal-coliform concentrations exceeding standards. Public pressure to investigate the cause of fecal-coliform concentrations exceeding standards and solve the problem that caused the closure prompted various State agencies to cooperatively survey the sanitary quality of the area in 1993-94. The results of the sanitary survey led to the conditional reopening of some parts of the Harbor in 1994. The sanitary-survey work documented the occurrence of high fecal-coliform concentrations, for up to 3 days, after storms; however, the work did not generate sufficient data to determine the threshold of rainfall that led to concentrations of fecal coliforms exceeding standards in the Harbor. Other Harbor related studies have shown that high fecal-coliform concentrations are observed in the Harbor for up to 3 days after a storm ends (New Hampshire Division of Public Health Services, 1994). Consequently, a conservative 0.10 in. rainfall threshold was adopted by the New Hampshire Division of Public Health Services. Although water-quality monitoring continued after 1994, few data were collected to explore the relation between rainfall and bacteria levels in the Harbor. Thus, the current management strategy of a conservative rainfall threshold essentially has remained unchanged since 1994, although a 1998 analysis of seasonal data resulted in a change to a 0.25 in. rainfall threshold for the winter months (December, January, February, March).

Since the late 1980's, the New Hampshire Department of Health and Human Services and NHDES have collected bacteriological data in the coastal region of New Hampshire. Other investigations have examined this historical fecal-coliform data for the Harbor for seasonal characteristics under dryweather conditions, wet-weather conditions, and compliance with National Shellfish Sanitation Program (NSSP) statistical criteria (Nash, 1999). The
NSSP fecal-coliform standards require that for a dataset of 30 samples, a geometric mean of no more than 14 most probable number per 100 milliliters (MPN/100mL), and not more than 10 percent of the samples exceed $43 \mathrm{MPN} / 100 \mathrm{~mL}\left(90^{\text {th }}\right.$ percentile statistic). If statistics for the dataset exceed these standards, restrictions on shellfish harvesting are imposed. Currently (2002), State regulations restrict softshell clam harvesting to Fridays and Saturdays from November to May. In 2000, of the 60 days available during the November-May shellfish harvesting open season, only 23 days (38 percent) were open for harvesting; in 2001, 31 days (52 percent) were open for harvesting. With the exception of one closure related to partially treated sewage overflow, all of the closures were related to rainfall events (Nash and Chapman, 2001; Nash, 2002).

Results from the analysis of historical data (1988-99) show that concentrations of fecal coliforms generally were below standards under dry-weather conditions, but exceeded standards with increased rainfall. Seasonal variation was observed in the historical data. Samples collected during the fall showed high fecal-coliform concentrations with nearly all storms regardless of rainfall amounts. Unusually high fecal-coliform concentrations were associated with some dry-weather sampling events (samples collected after 3 days of no precipitation) in the early to mid fall. Samples collected during the spring show high fecalcoliform concentrations with moderate to large amounts of rainfall, but almost no high fecal-coliform concentrations were associated with winter rainfalls (Nash, 1999). The analysis of the historical data provided the basis for the design and implementation of a supplemental monitoring effort (2000-01), by the U.S. Geological Survey (USGS) and NHDES, for the Harbor to improve the understanding of fecal-coliform concentrations in relation to specific environmental factors. Environmental factors include rainfall, salinity, turbidity, water temperature, wind speed, wind direction, air temperature, qualitative counts on bird populations, and basin characteristics such as area served by municipal sewer, on-site septic systems, and population density. From this basis, the USGS, in cooperation with the NHDES developed a study of the occurrence of fecal coliforms in water and the potential environmental factors that affect fecalcoliform concentrations at the Harbor in New Hampshire. This study provided a better 
understanding of the environmental factors that ultimately affect shellfish harvesting in the Harbor. It also provided the NHDES Shellfish Program an expanded dataset to help determine effects of rainfall on fecal coliforms, as well as data from sites on tributaries entering the Harbor. The expanded dataset also was used to update the sanitary-survey report, by NHDES, for the Harbor.

\section{Purpose and Scope}

This report (1) describes the spatial and temporal distribution of fecal-coliform concentrations, (2) determines the relation between fecal-coliform concentrations and environmental factors, and (3) determines the degree to which environmental factors explain the variability of fecal-coliform concentrations in the Harbor.

The data discussed were collected from 10 sites in the Harbor that were sampled routinely (monthly) and on a rainfall-event basis. Five additional sites in the Harbor and eight sites on tributaries entering the Harbor were sampled less frequently than the 10 Harbor sites and when personnel were available. Data on environmental factors collected at the time of sampling included rainfall, salinity, turbidity, water temperature, wind speed, wind direction, air temperature, and qualitative counts on bird populations. Basin characteristics such as area served by municipal sewer, on-site septic systems, and population density were also calculated for a subset of sites. Over 90 percent of the samples were collected during the spring and fall and will be the major focus of results in this report.

\section{Previous Studies}

Studies have shown that fecal-indicator bacteria concentrations can be related to environmental factors such as salinity, temperature, and turbidity. Painchaud and others (1995) reported that bacteria exhibited the highest mean concentrations at a freshwater sampling site and lowest mean concentrations at a saline sampling site. Bacteria numbers declined exponentially relative to salinity. Roper and Marshall (1979) reported that an increase in salinity resulted in a corresponding decline of coliform bacteria in water. Puddu and others (1998) indicated that bacterial activity and mean concentrations of bacteria were higher in warm, low-salinity waters than in warm, high-salinity waters; and in general, warm water was more susceptible to bacterial activity than cold water. Grimes (1980) found that fecal-indicator bacteria concentrations correlated with turbidity downstream from dredging activities. Tunnicliff and Brickler (1984) also found a statistically significant correlation between turbidity and fecal-coliform concentrations in samples collected during storms but not for samples collected during base flow.

In other studies, investigators demonstrated the relations between fecal-indicator bacteria and environmental factors such as rainfall, wind speed and direction, and wave heights. Struck (1988) indicated that fecal-coliform concentrations showed a significant relation to rainfall amounts. Two studies indicated a relation between fecal-indicator bacteria, wind speed and direction, and wave height (Lehman and Fogel, 1976; Aldom and others, 1998). Francy and Darner (1998) found that Escherchia coli concentrations were related to turbidity, rainfall, and wave height at Lake Erie public bathing beaches. These factors accounted for 58 percent of the variation in Escherchia coli concentrations (Francy and Darner, 1998).

Frenzel and Couvillion (2002) found that areas served by sewer systems had significantly higher concentrations of fecal-indicator bacteria than did areas served by septic systems. The areas served by sewer systems also had storm drains that discharged directly to streams, but storm drains were not present in the areas served by septic systems. Areas served by municipal sewers generally had higher population densities than areas served by septic systems. The higher population density, combined with storm drains from these areas discharging directly to the stream likely were affecting bacteria concentrations.

\section{Description of Study Area}

The Harbor study area is part of a shallow, barbuilt estuary in southeastern New Hampshire (fig. 1). Nearly 80 percent of the $47 \mathrm{mi}^{2}$ estuarine drainage basin is in the towns of Hampton, Hampton Falls, and Seabrook, N.H. The remaining drainage area is in Massachusetts. The eastern part of the estuary, commonly referred to as Hampton/Seabrook Harbor, encompasses approximately 600 acres of tidal waters at high tide. Almost 450 acres of tidal waters comprise a number of tributaries and account for the rest of the estuarine area. The topography of the basin 


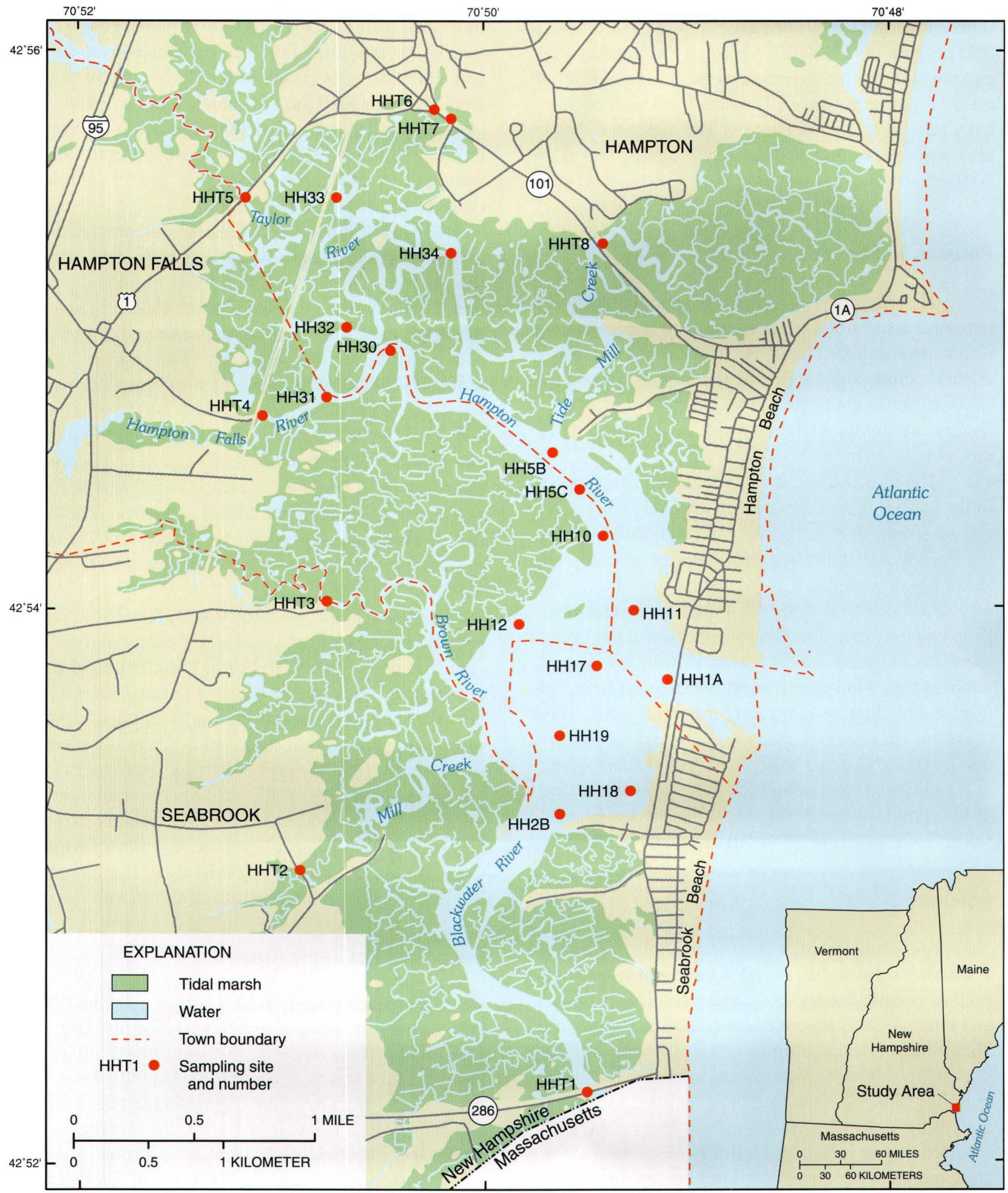

Base from U.S Geological Survey digital line graph data, 1:24,000

Hampton, N.H., photorevised, 1973; Newburyport East, Mass.-N.H., 1966

Figure 1. Hampton/Seabrook Harbor and tributaries, and sampling sites, southeastern New Hampshire. 
is relatively flat; and although approximately

60 percent of the basin is either forested or wetland, the basin is among the most intensively developed in coastal New Hampshire. Rubin and Merriam (1998) estimate that 18,37 , and 38 percent of the land in Hampton Falls, Hampton, and Seabrook, respectively, is developed. Development bordering the estuary primarily is residential and concentrated in the beach areas on the eastern shore (Jones, 2001).

Tidal exchange dominates circulation in the Harbor. A mixed, semi-diurnal tide with diurnal inequalities that are more pronounced on spring tides is common in coastal New Hampshire. Mean tidal range in the Harbor is $8.3 \mathrm{ft}$; the spring tidal range is $9.5 \mathrm{ft}$. The tides ebb and flood through one outlet to the Atlantic Ocean. Approximately 88 percent of the estuarine volume is exchanged over one tidal cycle. This high flushing rate, coupled with relatively small inputs of freshwater and generally shallow depths, explain the well-mixed nature of the estuarine waters. Salinity stratification is minor in the upper estuary following spring snowmelt and rainfall events, and water temperature stratification is minor during the summer.

\section{Acknowledgments}

The authors especially thank Andrew Chapman, New Hampshire Department of Environmental Services, and Michael Brayton, U. S. Geological Survey, for their assistance with field work. We also thank Natalie Landry, New Hampshire Department of Environmental Services; Bruce Smith, New Hampshire Fish and Game; and Joanne McLaughlin, Office of State Planning, for their assistance in field work; Mona Freese, New Hampshire Department of Environmental Services, and personnel from the New Hampshire Department of Environmental Services laboratory for their willingness to perform weekend work during rainfall event sampling. Ron Sher and Al Legendre, Seabrook Station, deserve thanks for providing precipitation data. The authors also acknowledge the assistance of volunteers from the Great Bay Coast Watch, University of New Hampshire Cooperative Extension/Sea Grant program who assisted in data collection during periods of personnel shortages. Appreciation is extended to Ann Marie Squillacci for manuscript preparation, Tina Cotton for graphics assistance, and Matt Cooke for the editorial review of this report (all from the USGS).

\section{DATA-COLLECTION AND ANALYSIS METHODS}

Water samples were collected on a routine (monthly) and rainfall-event basis (table 1) at 10 sites within the Harbor. Five additional Harbor sites and eight tributary sites were sampled only when personnel were available. Most statistical methods used in the analysis are described in detail in Helsel and Hirsch (1992).

\section{Sample Collection and Analysis}

Water samples collected on a rainfall-event basis consisted of both sampling before a predicted rainfall and after the rainfall event. A grab-sampling technique that minimized contamination of the sterile sample-collection containers was used to collect water samples (Myers and Sylvester, 1997). A boat was used to collect samples within the Harbor and samples at tributary sites were collected either by wading or by using an extension rod to which the sampling bottle was attached and extended into the center of flow. Water samples were chilled and transported to the NHDES Laboratory for analysis.

At the time of sample collection, a Reotemp dial thermometer was used to measure water and air temperature; a Kestrel 2000 wind meter measured wind speed; and a compass was used to estimate wind direction. Qualitative counts on bird populations and other relevant observations were noted. An additional water sample was collected at each site and chilled for measurement of $\mathrm{pH}$ (Orion model 250A meter), salinity (Orion model 125 meter), and turbidity (Hach 2100P meter) at the USGS New Hampshire/ Vermont District Laboratory.

Analytical methods used in this study follow the National Shellfish Sanitation Program (NSSP) guidelines and quality-assurance procedures. The procedures are outlined in the Quality Assurance Project Plan of the NHDES Shellfish Program (Chapman and Nash, 2002). Water samples taken in the Harbor were analyzed for fecal-coliform concentrations by the 5 -tube Most Probable Number test using laurel tryptose and EC-mug broth (American Public Health Association, American Water Works Association, and Water Pollution Control Federation, 1995). Fecal-coliform concentrations were reported as Most Probable Number per 100 milliliters. The mFC membrane-filtration method was used to analyze water samples collected at the tributary sites to the Harbor 
Table 1. Sampling site locations in Hampton/Seabrook Harbor and tributaries, New Hampshire

[fig., figure; HH, Hampton/Seabrook Harbor; ${ }^{\circ}$, degrees; ', minutes; ", seconds; HHT, Hampton/Seabrook Harbor tributaries]

\begin{tabular}{|c|c|c|c|}
\hline $\begin{array}{l}\text { Sampling site } \\
\text { (fig. 1) }\end{array}$ & Latitude & Longitude & General location description \\
\hline & & & Hampton/Seabrook Harbor \\
\hline HH1A & $42^{\circ} 53^{\prime} 45^{\prime \prime}$ & $70^{\circ} 49^{\prime} 04^{\prime \prime}$ & Route $1 \mathrm{~A}$ bridge, center of channel \\
\hline $\mathrm{HH} 2 \mathrm{~B}$ & $42^{\circ} 53^{\prime} 16^{\prime \prime}$ & $70^{\circ} 49^{\prime} 36^{\prime \prime}$ & Blackwater River near River Street \\
\hline HH5B & $42^{\circ} 54^{\prime} 34^{\prime \prime}$ & $70^{\circ} 49^{\prime} 38^{\prime \prime}$ & Mouth of Tide Mill Creek \\
\hline $\mathrm{HH} 5 \mathrm{C}$ & $42^{\circ} 54^{\prime} 26^{\prime \prime}$ & $70^{\circ} 49^{\prime} 30^{\prime \prime}$ & Hampton River channel \\
\hline HH10 & $42^{\circ} 54^{\prime} 16^{\prime \prime}$ & $70^{\circ} 49^{\prime} 23^{\prime \prime}$ & Hampton River channel, near Hampton Marina \\
\hline HH11 & $42^{\circ} 53^{\prime} 60^{\prime \prime}$ & $70^{\circ} 49^{\prime} 14^{\prime \prime}$ & Confluence of Hampton and Browns River \\
\hline HH12 & $42^{\circ} 53^{\prime} 57^{\prime \prime}$ & $70^{\circ} 49^{\prime} 48^{\prime \prime}$ & Browns River, just upstream from confluence with Hampton River \\
\hline HH17 & $42^{\circ} 53^{\prime} 48^{\prime \prime}$ & $70^{\circ} 49^{\prime} 25^{\prime \prime}$ & Blackwater River channel, near northern corner of Middle Ground \\
\hline HH18 & $42^{\circ} 53^{\prime} 21^{\prime \prime}$ & $70^{\circ} 49^{\prime} 15^{\prime \prime}$ & Seabrook Harbor, just upstream of Yankee fishing cooperative \\
\hline HH19 & $42^{\circ} 53^{\prime} 33^{\prime \prime}$ & $70^{\circ} 49^{\prime} 36^{\prime \prime}$ & Blackwater River channel near mouth of Mill Creek \\
\hline НH30 & $42^{\circ} 54^{\prime} 56^{\prime \prime}$ & $70^{\circ} 50^{\prime} 26^{\prime \prime}$ & Hampton Falls River channel \\
\hline НH31 & $42^{\circ} 54^{\prime} 46^{\prime \prime}$ & $70^{\circ} 50^{\prime} 45^{\prime \prime}$ & Hampton Falls River channel \\
\hline HH32 & $42^{\circ} 55^{\prime} 01^{\prime \prime}$ & $70^{\circ} 50^{\prime} 39^{\prime \prime}$ & Taylor River channel \\
\hline HH33 & $42^{\circ} 55^{\prime} 29^{\prime \prime}$ & $70^{\circ} 50^{\prime} 42^{\prime \prime}$ & Taylor River channel \\
\hline НH34 & $42^{\circ} 55^{\prime} 17^{\prime \prime}$ & $70^{\circ} 50^{\prime} 08^{\prime \prime}$ & Taylor River channel \\
\hline \multicolumn{4}{|r|}{ Hampton/Seabrook Harbor tributaries } \\
\hline HHT1 & $42^{\circ} 52^{\prime} 16^{\prime \prime}$ & $70^{\circ} 49^{\prime} 28^{\prime \prime}$ & Blackwater River at Route 286 bridge \\
\hline HHT2 & $42^{\circ} 53^{\prime} 04^{\prime \prime}$ & $70^{\circ} 50^{\prime} 53^{\prime \prime}$ & Mill Creek at Causeway Street \\
\hline HHT3 & $42^{\circ} 54^{\prime} 02^{\prime \prime}$ & $70^{\circ} 50^{\prime} 45^{\prime \prime}$ & Browns River near Seabrook Station \\
\hline HHT4 & $42^{\circ} 54^{\prime} 42^{\prime \prime}$ & $70^{\circ} 51^{\prime} 04^{\prime \prime}$ & Hampton Falls River at Depot Road \\
\hline HHT5 & $42^{\circ} 55^{\prime} 29^{\prime \prime}$ & $70^{\circ} 51^{\prime} 09^{\prime \prime}$ & Taylor River at Route 1 bridge \\
\hline HHT6 & $42^{\circ} 55^{\prime} 48^{\prime \prime}$ & $70^{\circ} 50^{\prime} 13^{\prime \prime}$ & Storm culvert at Route 101 offramp \\
\hline HHT7 & $42^{\circ} 55^{\prime} 46^{\prime \prime}$ & $70^{\circ} 50^{\prime} 08^{\prime \prime}$ & Storm culvert at Route 101 offramp \\
\hline HHT8 & $42^{\circ} 55^{\prime} 19^{\prime \prime}$ & $70^{\circ} 49^{\prime} 23^{\prime \prime}$ & Tide Mill Creek at Route 101 bridge \\
\hline
\end{tabular}

(American Public Health Association, American Water Works Association, and Water Pollution Control Federation, 1995). Concentrations of fecal coliform were reported as colonies per 100 milliliters.

\section{Statistical Methods}

Statistical tests were used to identify relations between fecal-coliform concentrations and environmental factors. A Spearman rho correlation test was used to determine the strength of association between two variables such as fecal-coliform concentrations and turbidity (Helsel and Hirsch, 1992). Boxplots and histograms were examined to determine the distributions of fecal-coliform concentrations (SAS Institute, Inc., 1998). These plots and test showed that the data were not normally distributed. Fecal-coliform concentrations and some environmental factors were log transformed for the regression analyses. Statview (SAS Institute, Inc., 1998) and Mathsoft S-Plus 2000 statistical software (Mathsoft, Inc., 1999) were used to perform all statistical analysis.

The Mann-Whitney statistical test was used to determine significant statistical differences between medians of two groups of data, such as samples collected during the spring and fall. If more than two groups of data were compared, the Kruskal-Wallis, a non-parametric analysis of variance test (ANOVA) was used to determine significant statistical differences among the data groups (Helsel and Hirsch, 1992). The level of significance for ANOVA was set at alpha equal to 0.05 . When the non-parametric ANOVA indicated significant statistical differences, the Tukey's multiple-comparison test was used to determine which groups were significantly different (Helsel and Hirsch, 1992). 
Linear-regression analysis was used to determine variance in fecal-coliform concentrations in water from one or more variables. Stepwise regression initially was used to guide the evaluation of which variables to include in the regression model. Simplelinear regression was used to describe the relation between fecal coliforms and one variable. Multiplelinear regression was used to describe the relation between fecal coliforms and multiple variables.

\section{CHARACTERIZATION OF FECAL-COLIFORM CONCENTRATIONS AND RELATIONS WITH ENVIRONMENTAL FACTORS}

Fecal-coliform data collected from 1988 to 1999 (termed historical data in the report) for the Harbor, combined with data collected from this investigation (2000-01), were used to characterize the spatial and temporal distribution of fecal-coliform concentrations at sampling sites. Data also were grouped and summarized by season and by tide cycles, to determine if concentrations between seasons and between tide cycles differed. Data also were examined in relation to rainfall categories to determine if correlations were present between rainfall amounts and fecal-coliform concentrations.

\section{Concentrations of Fecal Coliforms in Water Among Sampling Sites}

Summary statistics of all fecal-coliform data collected during the USGS/NHDES monitoring program are shown by sampling site in table 2 . Median concentrations of fecal coliform in the Harbor generally were highest at site HH19 (table 2). Median concentrations exceeded the geometric-mean standard of $14 \mathrm{MPN} / 100 \mathrm{~mL}$ at sites HH1A, HH2B, HH12, and HH19. Site HH19 exceeded the geometric-mean standard of $14 \mathrm{MPN} / 100 \mathrm{~mL}$ on more days than any other site in the Harbor. Median fecal-coliform concentrations at tributary sites were highest at sites HHT2, HHT6, and HHT7 (table 2). HHT2 and sites HHT6 and HHT7, which are stormwater culverts, had lower flows compared to other tributary sites. Less dilution at these sites may be one reason for the high fecal-coliform concentrations. HHT2 is on Mill Creek, which flows into the Harbor at site HH19.
Table 2. Summary statistics for fecal-coliform concentrations at sampling sites in Hampton/Seabrook Harbor and tributaries, New Hampshire

[fig., figure; No., number; NSSP, National Shellfish Sanitation Program MPN, Most Probable Number; HH, Hampton/Seabrook Harbor; HHT, Hampton/Seabrook Tributary; <, less than; N/A, not applicable; USGS, U.S. Geological Survey; NHDES, New Hampshire Department of Environmental Services]

\begin{tabular}{|c|c|c|c|c|c|c|}
\hline $\begin{array}{l}\text { Sam- } \\
\text { pling } \\
\text { site } \\
\text { (fig. 1) }\end{array}$ & $\begin{array}{l}\text { Medi- } \\
\text { an }\end{array}$ & $\begin{array}{l}\text { Mini- } \\
\text { mum }\end{array}$ & $\begin{array}{c}\text { Maxi- } \\
\text { mum }\end{array}$ & $\begin{array}{c}\text { No. of } \\
\text { samples }\end{array}$ & $\begin{array}{l}\text { No. of sam- } \\
\text { ples NSSP } \\
\text { criteria was } \\
\text { exceeded } \\
(14 \mathrm{MPN})^{2}\end{array}$ & $\begin{array}{l}\text { No. of sam- } \\
\text { ples NSSP } \\
\text { criteria was } \\
\text { exceeded } \\
(43 \mathrm{MPN})^{2}\end{array}$ \\
\hline & \multicolumn{6}{|c|}{$\begin{array}{c}\text { Hampton/Seabrook Harbor, in Most Probable Number } \\
\text { per } 100 \text { milliliters }\end{array}$} \\
\hline HH1A & 17 & $<2$ & 1,600 & 83 & 44 & 33 \\
\hline $\mathrm{HH} 2 \mathrm{~B}$ & 17 & $<2$ & 220 & 82 & 45 & 25 \\
\hline HH5B & 13 & $<2$ & 240 & 78 & 38 & 14 \\
\hline $\mathrm{HH} 5 \mathrm{C}$ & 11 & $<2$ & 1,600 & 82 & 38 & 19 \\
\hline HH10 & 8 & $<2$ & 350 & 84 & 32 & 16 \\
\hline HH11 & 12 & $<2$ & 350 & 82 & 41 & 25 \\
\hline HH12 & 17 & $<2$ & 500 & 85 & 45 & 27 \\
\hline HH17 & 13 & $<2$ & 350 & 82 & 41 & 30 \\
\hline HH18 & 13 & $<2$ & 240 & 81 & 41 & 28 \\
\hline HH19 & 22 & $<2$ & 540 & 85 & 51 & 33 \\
\hline НH30 & 2 & $<2$ & 350 & 45 & 13 & 6 \\
\hline HH31 & 8 & $<2$ & 240 & 42 & 13 & 6 \\
\hline HH32 & 5 & $<2$ & 130 & 42 & 7 & 4 \\
\hline HH33 & 8 & $<2$ & 350 & 42 & 12 & 4 \\
\hline HH34 & 8 & $<2$ & 240 & 44 & 13 & 3 \\
\hline \multicolumn{7}{|c|}{$\begin{array}{c}\text { Hampton/Seabrook Tributary, in colonies } \\
\text { per } 100 \text { milliliters }\end{array}$} \\
\hline HHT1 & 6 & 0 & 64 & 35 & N/A & N/A \\
\hline HHT2 & 74 & 1 & 2,500 & 35 & N/A & N/A \\
\hline HHT3 & 5 & 0 & 122 & 34 & N/A & N/A \\
\hline HHT4 & 10 & 1 & 450 & 35 & N/A & N/A \\
\hline HHT5 & 21 & 0 & 370 & 34 & N/A & N/A \\
\hline НHT6 & 92 & 3 & 4,300 & 35 & N/A & N/A \\
\hline HHT7 & 57 & 0 & 2,000 & 35 & N/A & N/A \\
\hline HHT8 & 11 & 0 & 138 & 35 & N/A & N/A \\
\hline
\end{tabular}

${ }^{1}$ Number of samples collected during the USGS/NHDES monitoring program (2000-01). Generally, sites with fewer samples were sites that were sampled when additional personnel were available.

${ }^{2}$ Criteria concentration is based on the geometric mean of the previous 30 samples in shellfish waters under conditions when Hampton/Seabrook Harbor is open to clam harvesting. Comparisons to the criteria in this study only are for qualitative purposes and not for NSSP purposes. 


\section{Seasonal and Tidal Effects on Fecal-Coliform Concentrations}

Statistical tests indicate that fecal-coliform concentrations are significantly different $(\mathrm{p}<0.05)$ among seasons, except for spring and winter (fig. 2). Warmer-water temperatures and the increase in population in the summer and portions of the fall, compared to winter and spring, may be one reason for higher fecal-coliform concentrations during these seasons. Fecal-indicator bacteria are capable of greater production in warm water than in cold water (Puddu and others, 1998).

Data from this investigation (2000-01) were compared with historical data (1988-99). The data grouped by season, and categorized by historical and current data, are shown in figure 3. Statistical-test results between the two groups of data in each season show no significant statistical differences $(\mathrm{p}>0.05)$. This result indicates that water samples collected during this study (2000-01) were representative of the historical (1988-99) water samples.

Samples for this study typically were not collected during summer (when the Harbor is closed for shellfish resource conservation reasons) and were collected only monthly throughout the winter. In the spring and fall, monthly and rainfall-event sampling occurred, which resulted in much larger datasets for those periods. Samples collected during spring and fall 2000 and 2001 were compared to determine seasonal differences in the data. The data indicate a significant statistical difference among fecal-coliform concentrations between samples collected during the spring and fall $(\mathrm{p}<0.05)$.

Tidal cycles occur over 14 days. Samples collected during the midpoint of the tide cycles (change in cycle) were not used for comparison among the two tide groups because the samples collected during these conditions may not truly represent either tidal cycle. Percentiles from the range of tide heights during sample collection were used to group tidal data. Water samples collected at tide heights greater than the $75^{\text {th }}$ (high tide heights) or less than the $25^{\text {th }}$ (low tide heights) percentiles were used in the comparison. Generally, samples collected during neap-tide cycles (usually the lowest of the low tide heights) had higher ranges of fecal-coliform concentrations than the ranges in samples collected during spring-tide cycles (usually the highest of the high tide heights) (fig. 4). In general, samples also had lower measurements of salinity when collected during neap-tide cycles compared to samples collected during spring-tide cycles (fig. 5). Bacteria survival and production in more saline waters is less than that of survival and production in freshwater (Puddu and others, 1998; Painchaud and others, 1995). Dilution from a greater volume of ocean water during spring-tide cycles also may affect fecal-coliform concentrations.

\section{Relation between Rainfall and Fecal-Coliform Concentrations}

Median and geometric-mean concentrations of fecal coliform by rainfall category from current data (2000-01) are shown in table 3. Fecal-coliform data for the Harbor and tributary sites were grouped separately because of the different methods used for laboratory analysis. Fecal-coliform data shown in table 3 indicate that most of the median concentrations increased in the Harbor and the tributary sites as rainfall amounts increased. The exception is the concentrations of fecal coliform for the rainfall amounts equal to or greater than 0.1 and less than 0.25 in. at tributary sites. Median and geometric-mean concentrations for samples collected in this rainfall category were lower than fecal-coliform concentrations for samples collected in the category of less than 0.1 in. of rainfall. This decrease may be because of the small sample size for this particular rainfall category.

Table 3. Median and geometric-mean concentrations of fecal coliform by rainfall category at Hampton/Seabrook Harbor and tributaries, New Hampshire

[Rainfall, in inches, is the amount that fell on the day of sampling (before sample collection) and the previous 3 days before sampling; No., number; $<$, less than; $\geq$, greater than or equal to]

\begin{tabular}{|c|c|c|c|}
\hline $\begin{array}{l}\text { Rainfall, } \\
\text { in inches }\end{array}$ & Median & $\begin{array}{l}\text { Geometric } \\
\text { mean }\end{array}$ & $\begin{array}{c}\text { No. of } \\
\text { samples }\end{array}$ \\
\hline \multicolumn{4}{|c|}{$\begin{array}{c}\text { Hampton/Seabrook Harbor sites, in Most Probable Number } \\
\text { per } 100 \text { milliliters }\end{array}$} \\
\hline$<0.1$ inch & 4.5 & 6.4 & 522 \\
\hline$\geq 0.1$ and $<0.25$ inch & 17 & 13 & 109 \\
\hline$\geq 0.25$ and $<0.5$ inch & 17 & 14 & 186 \\
\hline$\geq 0.5$ inch & 33 & 30 & 266 \\
\hline \multicolumn{4}{|c|}{ Tributary sites, in colonies per 100 milliliters } \\
\hline$<0.1$ inch & 14 & 13 & 142 \\
\hline$\geq 0.1$ and $<0.25$ inch & 2.0 & 2.4 & 18 \\
\hline$\geq 0.25$ and $<0.5$ inch & 21 & 26 & 81 \\
\hline$\geq 0.5$ inch & 41 & 48 & 71 \\
\hline
\end{tabular}




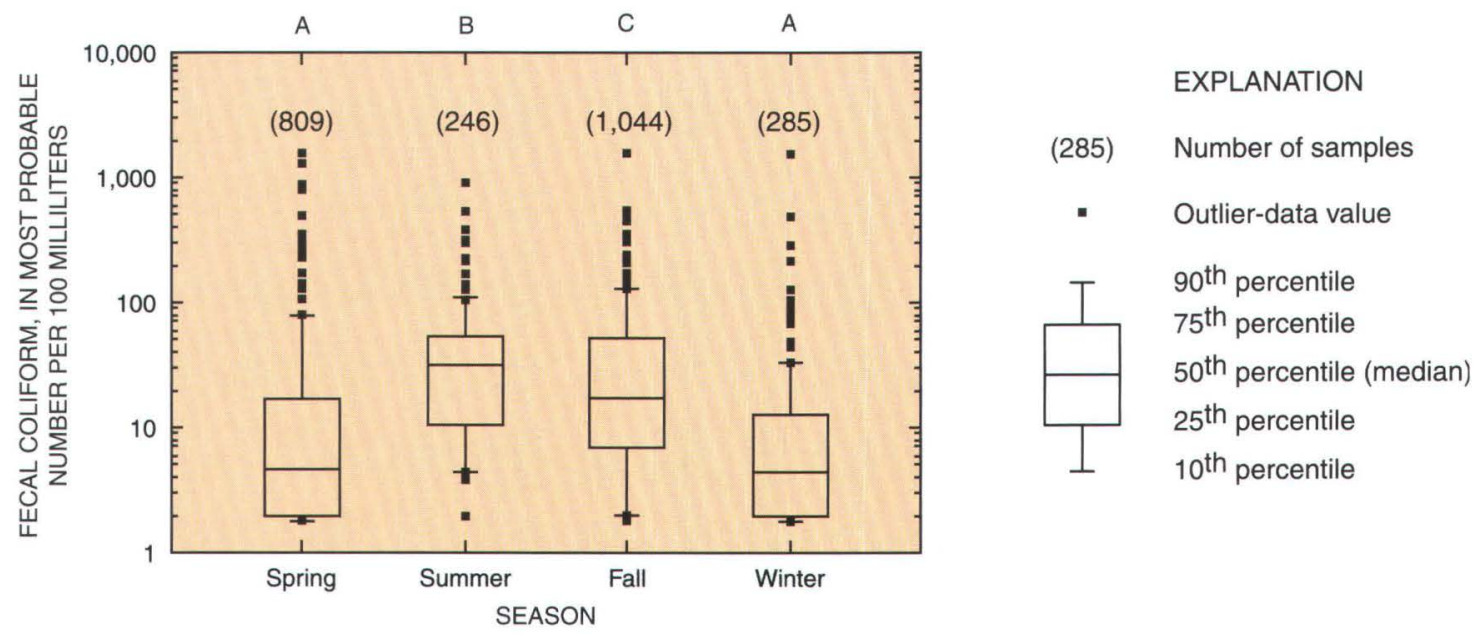

Figure 2. Range of fecal-coliform concentrations by season at Hampton/Seabrook Harbor, New Hampshire. Results of Tukey's multiple-comparison test (Helsel and Hirsch, 1992) are presented as letters, and concentrations with at least one letter in common do not differ significantly; for example, spring and winter concentrations do not differ significantly.
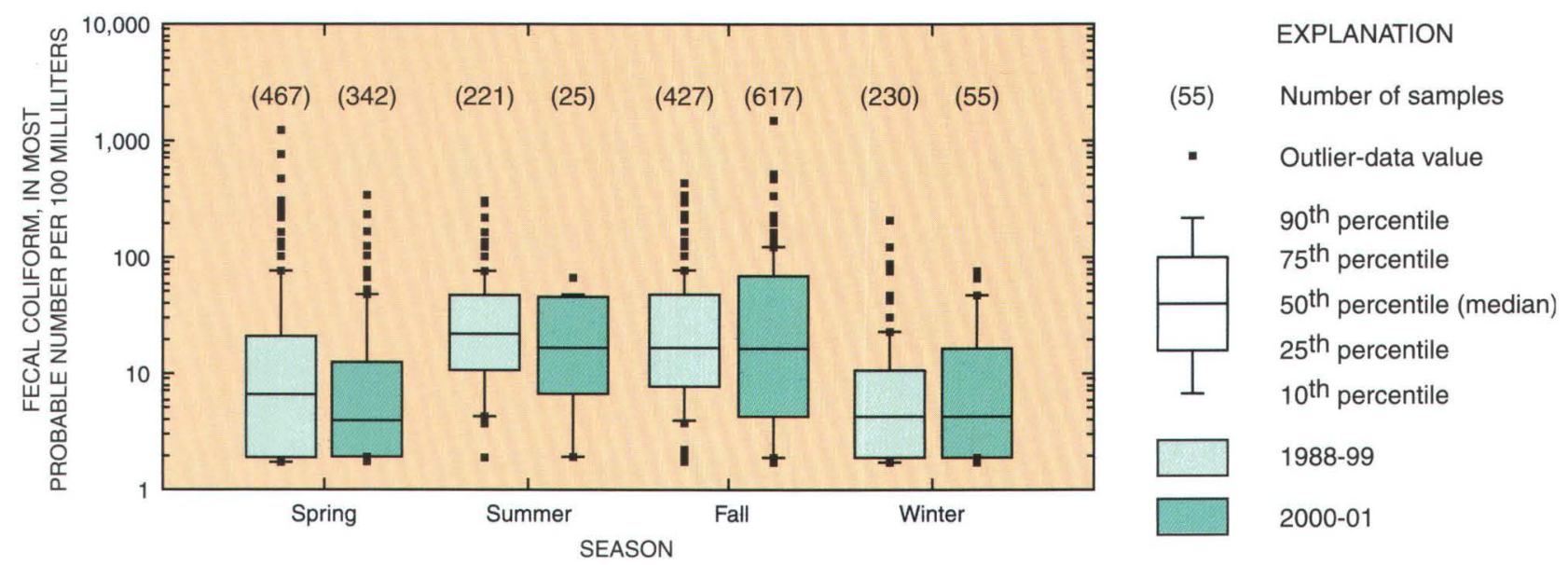

Figure 3. Range of fecal-coliform concentrations for historical (1988-99) and current (2000-01) data in relation to season at Hampton/Seabrook Harbor, New Hampshire. 


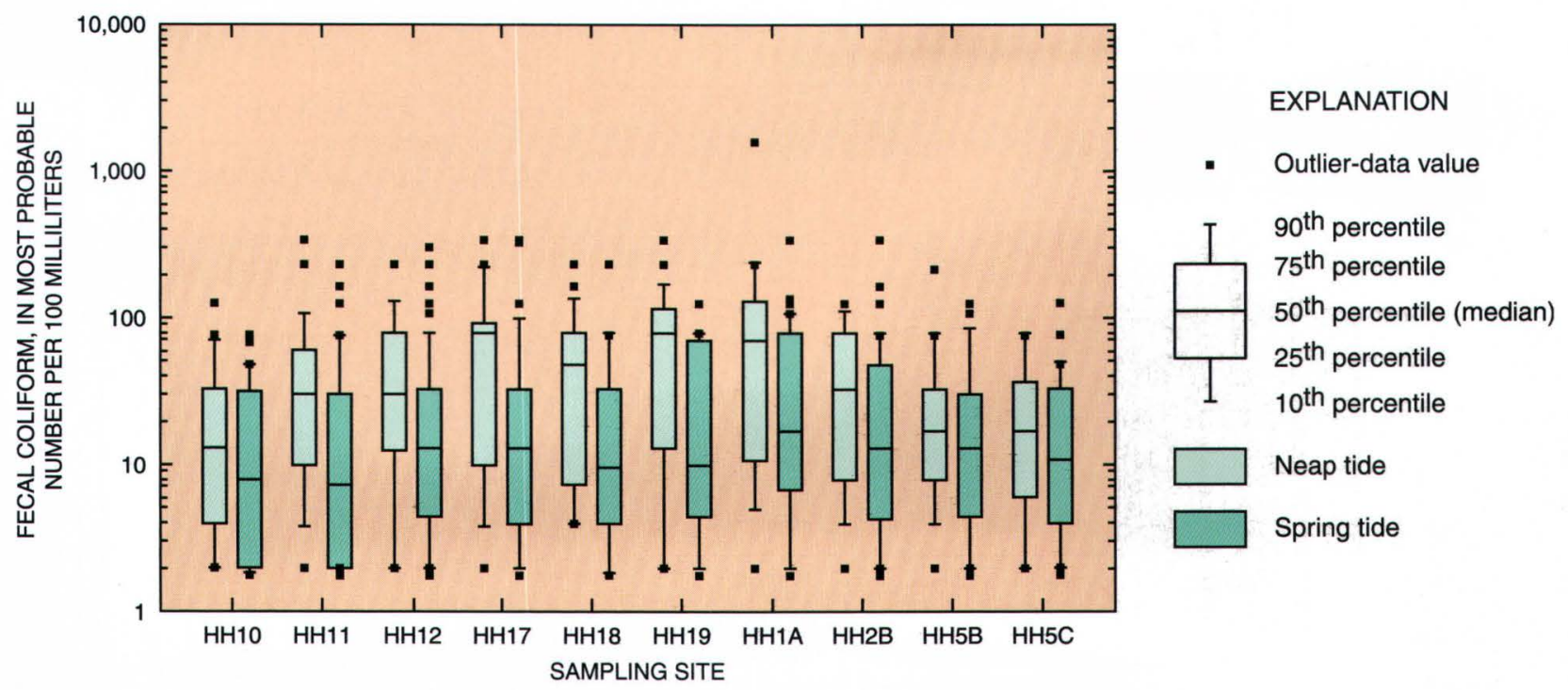

Figure 4. Range of fecal-coliform concentrations by tide cycle at sampling sites in Hampton/Seabrook Harbor, New Hampshire. Sampling sites are shown on figure 1.

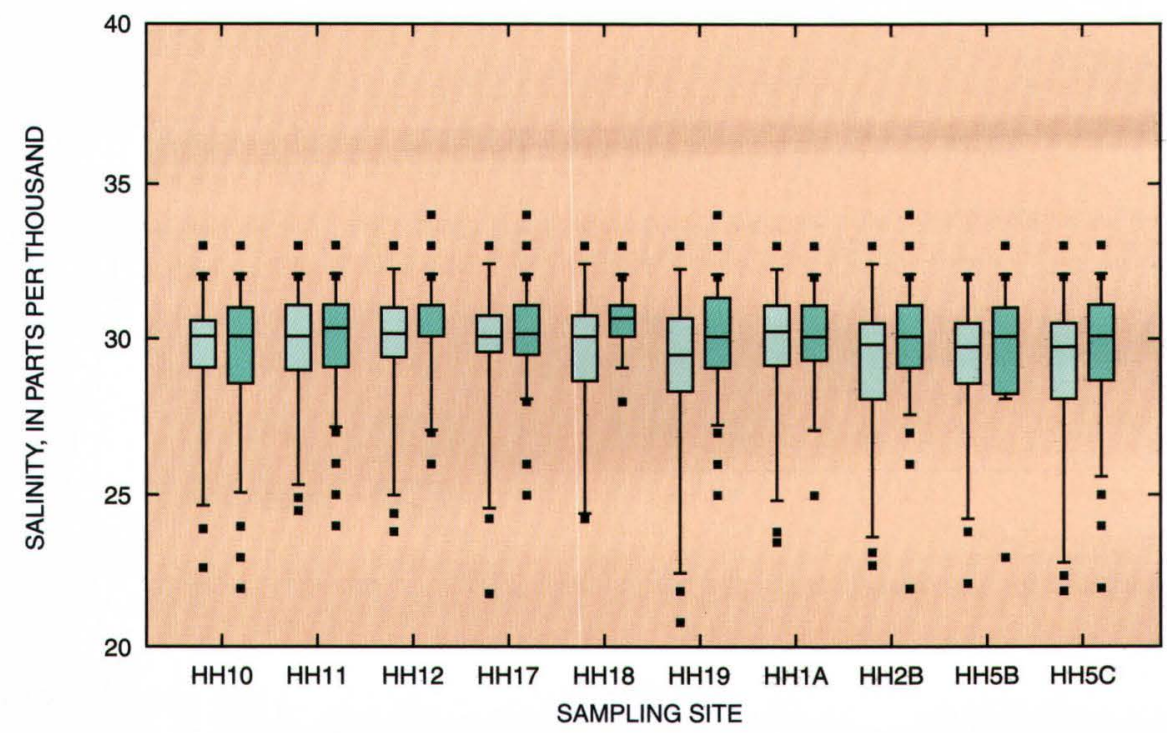

\section{EXPLANATION}

- Outlier-data value

Toth percentile $75^{\text {th }}$ percentile $50^{\text {th }}$ percentile (median) $25^{\text {th }}$ percentile $10^{\text {th }}$ percentile

Neap tide

Spring tide

Figure 5. Range of salinity concentrations by tide cycle at sampling sites in Hampton/Seabrook Harbor, New Hampshire. Sampling sites are shown on figure 1. 
The number of samples (18) collected for greater than or equal to 0.1 and less than 0.25 in. of rainfall at tributary sites was much lower than samples collected under the other rainfall categories (table 3). The comparison of the median and geometric-mean concentrations among the rainfall categories indicate that rainfall did affect fecal-coliform concentrations in the Harbor and tributary sites. Direct runoff from the land surface may be contributing to the increase in fecal-coliform concentrations during and after periods of rainfall events.

Historically, the total of the antecedent rainfall, in inches, within 3 days before sample collection, has been used to determine the effects on fecal-coliform concentrations in the Harbor (New Hampshire Division of Public Health Services, 1994). To determine if other rainfall variables may be related to fecal-coliform concentrations when compared to 3-day rainfall, six rainfall statistics were generated: (1) 1-day rainfall, (2) 2-day cumulative rainfall, (3) 3-day cumulative rainfall, (4) 4-day cumulative rainfall (5) weighted rainfall, and (6) peak and average intensity of a single rainfall, when applicable. Weighted rainfall was computed from the rainfall amounts that fell in the 4 days preceding the sampling, with the most recent rainfall receiving the highest weight. Rainfall amounts (before sampling) on the day of sample collection were multiplied by a factor of four. Rainfall amounts on the day before sampling were multiplied by three, rainfall amounts on 2 days before sampling were multiplied by two, and rainfall amounts on 3 days before sampling were multiplied by one. The four weighted terms then were summed to provide weighted rainfall for the time of sampling (Francy and Darner, 1998). Peak and average intensity of the rainfall during a storm also were analyzed in relation to fecal-coliform concentrations to determine if the intensity of storms affects fecal-coliform concentrations in the Harbor. Peak intensity is the largest amount of rain that fell hourly during the storm. Average intensity was defined as the average amount of rainfall per hour during the storm.

Correlation coefficients were computed to assess the relation between fecal-coliform concentrations and rainfall variables (table 4). Generally, the highest correlation coefficients were between fecalcoliform concentrations and rainfall $(\mathrm{p}<0.05$; rho $=0.27-0.59) ; 4$-day and weighted rainfall had the strongest correlations in both seasons $(\mathrm{p}<0.05$; rho $=$ $0.45-0.59$ ); peak and average intensity of the rainfall and 1-day rainfall had the weakest correlations with the fecal-coliform concentrations $(\mathrm{p}<0.05$; rho $=0.13-0.40)$ than 2-day, 3-day, 4-day and weighted rainfall.

\section{Relation between Other Environmental Factors and Fecal-Coliform Concentrations}

Other environmental factors (besides rainfall) tested for relations were (1) salinity, (2) turbidity, (3) water temperature, (4) wind speed, (5) percent sewer, (6) percent septic, and (7) population density. The relations between these environmental factors and fecal-coliform concentrations were not as strong as relations between fecal-coliform concentrations and rainfall. Sites that were used to test relations with basin characteristics, percent area served by municipal sewer, on-site septic systems, and population density, were those at the mouths of four tributaries in the Harbor (HH2B, HH5B, HH12, and HH19). Basin characteristics were calculated for the upstream area (Geolytics, Inc., 1998).

Salinity was not significantly correlated to fecalcoliform concentrations in the spring and showed a weak negative relation in the fall. Relations between fecal-coliform concentrations and turbidity were observed for samples collected in the spring $(\mathrm{p}<0.05$; rho $=0.45)$ but were not significant for samples collected in the fall. Negative relations between fecal-coliform concentrations and water temperature $(\mathrm{p}<0.05$; rho $=-0.21)$ and relations between fecal-coliform concentrations and wind speed $(\mathrm{p}<0.05$; rho $=-0.36)$ were observed for the spring. There were no significant relations between fecalcoliform concentrations and percent sewer or septic and population density (table 4).

Analysis of variance was used to assess the relation between wind measurements and fecalcoliform concentrations. For wind direction, data on fecal-coliform concentrations were placed into four categories on the basis of wind direction in degrees clockwise from north (NE $1-90^{\circ}$; SE $91-180^{\circ}$; SW $181-270^{\circ}$; NW $271-360^{\circ}$ ) (fig. 6). When winds were from the southwest at the time of sample collection, lower concentrations of fecal coliform $(\mathrm{p}<0.05)$ were observed than when winds were from the other three directions. Samples collected when winds were from the northwest (when most samples were collected) did not differ significantly $(\mathrm{p}>0.05)$ from samples collected when winds were from the northeast, or southeast, or when there was no wind. 
Table 4. Summary of correlations between fecal-coliform concentrations, rainfall variables, and environmental factors at Hampton/Seabrook Harbor, New Hampshire [NS, is not statistically significant at $\alpha=0.05$; n, number of samples]

\begin{tabular}{|c|c|c|c|c|c|c|c|c|c|c|c|c|c|c|}
\hline & $\underset{\text { rainfall }^{1}}{\text { 1-day }}$ & $\underset{\text { rainfall }^{2}}{\text { 2-day }}$ & $\begin{array}{l}\text { 3-day } \\
\text { rainfall }^{3}\end{array}$ & $\begin{array}{c}\text { 4-day } \\
\text { rainfall }^{4}\end{array}$ & $\begin{array}{l}\text { Weighted } \\
\text { rainfall }^{5}\end{array}$ & $\begin{array}{c}\text { Peak } \\
\text { intensity }^{6}\end{array}$ & $\begin{array}{c}\text { Average } \\
\text { intensity }^{7}\end{array}$ & Salinity & Turbidity & $\begin{array}{c}\text { Water } \\
\text { tempera- } \\
\text { ture }\end{array}$ & $\begin{array}{l}\text { Wind } \\
\text { speed }\end{array}$ & $\begin{array}{l}\text { Percent } \\
\text { sewer }^{8}\end{array}$ & $\begin{array}{l}\text { Percent } \\
\text { septic }^{8}\end{array}$ & $\begin{array}{c}\text { Popula- } \\
\text { tion } \\
\text { density }\end{array}$ \\
\hline \multicolumn{15}{|c|}{ Fecal-coliform concentration correlations } \\
\hline \multicolumn{15}{|c|}{ Spring data } \\
\hline $\begin{array}{l}\text { Spearman's } \\
\text { rho }\end{array}$ & NS & 0.27 & 0.36 & 0.45 & 0.49 & 0.25 & 0.13 & NS & 0.45 & -0.21 & -0.36 & NS & NS & NS \\
\hline $\mathrm{n}$ & 342 & 342 & 342 & 342 & 342 & 207 & 207 & 342 & 237 & 342 & 327 & 4 & 4 & 4 \\
\hline \multicolumn{15}{|c|}{ Fall data } \\
\hline $\begin{array}{l}\text { Spearman's } \\
\text { rho }\end{array}$ & .40 & .50 & .48 & .59 & .53 & .24 & .29 & -.17 & NS & .17 & NS & NS & NS & NS \\
\hline $\mathrm{n}$ & 617 & 617 & 617 & 617 & 617 & 283 & 283 & 568 & 452 & 617 & 598 & 4 & 4 & 4 \\
\hline
\end{tabular}

${ }^{1}$ Rainfall was the amount in inches that fell on the day of sampling before sample collection.

${ }^{2}$ Rainfall was the amount in inches that fell on the day of and day before sampling.

${ }^{3}$ Rainfall was the amount in inches that fell on the day of and 2 days before sampling.

${ }^{4}$ Rainfall was the amount in inches that fell on the day of and 3 days before sampling.

${ }^{5}$ Weighted rainfall was the amount in inches that fell on the day of and 3 days before sampling, with the most recent rainfall receiving the highest weight.

${ }^{6}$ Peak intensity is the largest amount of rainfall falling hourly during the rainfall event; determined from a subset of samples.

${ }^{7}$ Average intensity is the average amount of rainfall per hour during the rainfall event; determined from a subset of samples.

${ }^{8}$ Determined from a subset of samples that included Harbor sites near the mouth of rivers entering the Harbor and generally representing the upstream basin. The median fecal-coliform value from each site was used for comparison to these environmental factors. 

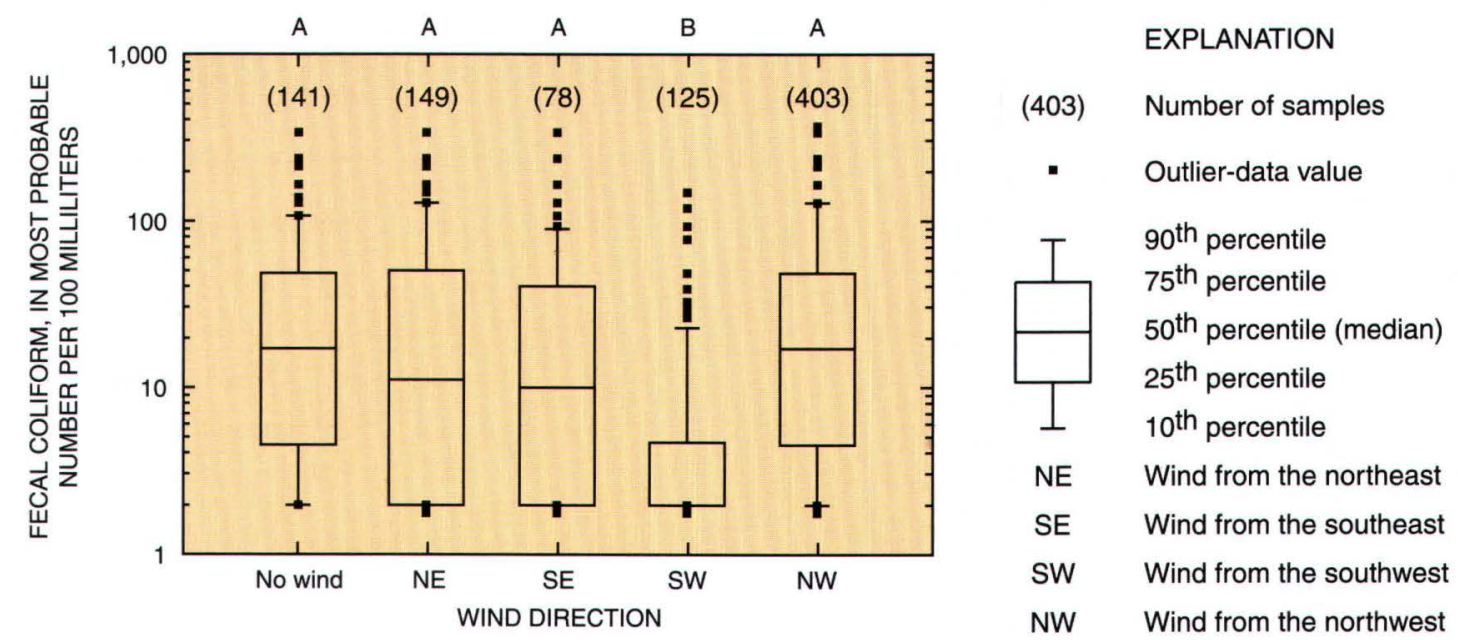

Figure 6. Range of fecal-coliform concentrations by wind direction at Hampton/Seabrook Harbor, New Hampshire. Results of Tukey's multiple-comparison test (Helsel and Hirsch, 1992) are presented as letters, and concentrations with at least one letter in common do not differ significantly; for example, concentrations measured during no wind, northeast, southeast, and northwest wind do not differ significantly.

For wind speed, the data were grouped into four categories: no wind, greater than 0-5 miles per hour (mph), greater than 5-10 $\mathrm{mph}$, and greater than $10 \mathrm{mph}$ (fig. 7). Data were not significantly different among most categories; however, samples collected during wind speeds of greater than 5-10 mph had significantly lower median concentrations than the concentrations of samples collected when there was no wind, or winds were greater than $0-5 \mathrm{mph}$ (fig. 7). This result may indicate that wind does not substantially affect fecal-coliform concentrations in the Harbor.

\section{EFFECTS OF ENVIRONMENTAL FACTORS ON FECAL-COLIFORM CONCENTRATIONS}

Environmental factors that were related to fecalcoliform concentrations were used to develop statistical equations that may be used to explain the variability in fecal-coliform concentrations. Regression analysis was used on both the spring and fall data to determine if different factors were affecting fecalcoliform concentrations on a seasonal scale. Simplelinear-regression analysis was used to determine the possibility of using one variable as a predictor of fecalcoliform concentrations. Rainfall was used as a single predictor of fecal-coliform concentrations. Regression statistics for prediction of fecal-coliform concentrations from four different rainfall variables are shown in table 5 .
The standard error of the regression line (S) measures the degree of deviation of observed values from the regression line and is an indicator of the level of uncertainty associated with a prediction, which is expressed as a percentage of the predicted mean. Standard errors ranged from about 51 to 62 percent for the different rainfall variables used to predict fecalcoliform concentrations (table 5). The slope of the regression line is a measure of the rate of change in $\log _{10}$ fecal coliform with the change in rainfall. The $y$-intercept is the value for the $\log _{10}$ fecal coliform that corresponds to a zero value for the variables used in the regression (Helsel and Hirsch, 1992). The $y$-intercepts from the data all were positive values, and t-test on the $y$-intercepts indicated that they were not significantly different from zero $(\mathrm{p}<0.01)$, with the exception of 1-day rainfall in the spring. The coefficient of determination $\left(\mathrm{R}^{2}\right)$ is the fraction of variation in $\log _{10}$ fecal-coliform concentrations that can be explained by the rainfall variable. For example, an $\mathrm{R}^{2}$ of 0.21 indicates that 21 percent of the variation in the $\log _{10}$ fecal-coliform concentrations can be explained by weighted-rainfall values (table 5 ). The $\mathrm{R}^{2}$ values using simple-linear regression for other environmental factors, such as salinity and turbidity, were low. Low $\mathrm{R}^{2}$ values found for the relations between fecal coliform and these factors indicate that other factors, or a combination of factors, may help explain the variability in fecal-coliform concentrations (Francy and Darner, 1998). 


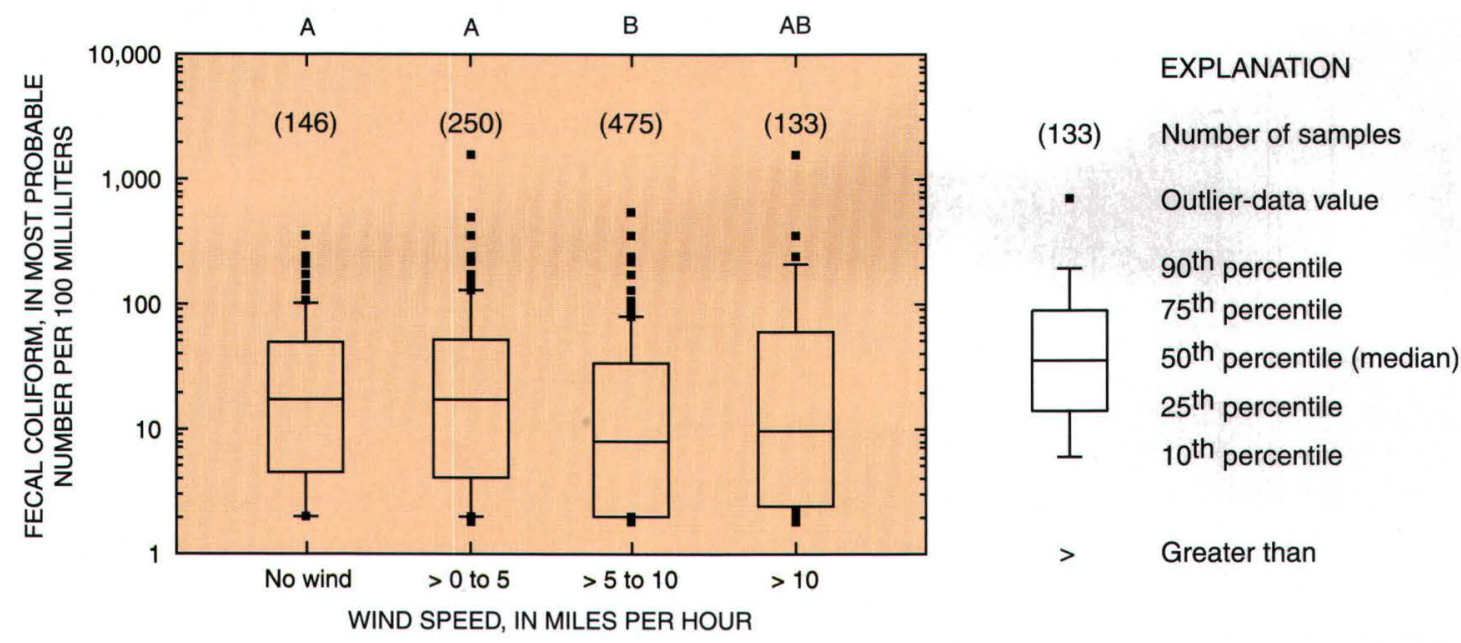

Figure 7. Range of fecal-coliform concentrations by wind speed at Hampton/Seabrook Harbor, New Hampshire. Results of Tukey's multiple-comparison test (Helsel and Hirsch, 1992) are presented as letters and concentrations with at least one letter in common do not differ significantly; for example, concentrations measured during no wind and greater than $0-5$ miles per hour do not differ significantly.

Table 5. Regression statistics for $\log _{10}$ fecal-coliform concentrations and rainfall variables for samples collected during the spring and fall at Hampton/Seabrook Harbor, New Hampshire

[No., number; The standard error of the regression (S) is the degree of uncertainty associated with a prediction of fecal-coliform concentrations from rainfall. The p-value of t-tests on the slopes of the regression lines is the probability that the null hypothesis (the slope is equal to zero) is true ( $=0.05$ ). The $y$-intercept is the value for $\log _{10}$ fecal coliform that corresponds to a zero value for rainfall. The $p$-value of t-tests on the y-intercepts of the regression lines is the probability that the null hypothesis (the $y$-intercept is equal to zero) is true $(=0.05)$. The coefficient of determination $\left(R^{2}\right)$ is the fraction of the variation in fecal-coliform concentration that can be explained by each rainfall; --, not determined; NS, not significant; <, less than]

\begin{tabular}{|c|c|c|c|c|c|c|c|}
\hline Dataset & $\begin{array}{c}\text { No. of } \\
\text { samples }\end{array}$ & $\begin{array}{c}\mathrm{S} \\
\text { (percent) }\end{array}$ & Slope & $\begin{array}{c}p \text {-value for } \\
\text { t-tests on slope }\end{array}$ & $y$-intercept & $\begin{array}{c}\text { p-values for } \\
\text { t-tests on } \\
y \text {-intercept }\end{array}$ & $\mathbf{R}^{2}$ \\
\hline \multicolumn{8}{|c|}{ Spring data } \\
\hline 1 -day rainfall ${ }^{1}$ & 342 & -- & -- & NS & -- & NS & -- \\
\hline 2-day rainfall ${ }^{2}$ & 342 & 53.1 & 0.741 & $<0.0001$ & 0.685 & $<0.0001$ & 0.10 \\
\hline 3-day rainfall ${ }^{3}$ & 342 & 54.0 & .496 & $<.0001$ & .672 & $<.0001$ & .07 \\
\hline 4-day rainfall ${ }^{4}$ & 342 & 50.7 & .317 & $<.0001$ & .651 & $<.0001$ & .18 \\
\hline Weighted rainfall ${ }^{5}$ & 342 & 49.8 & .279 & $<.0001$ & .567 & $<.0001$ & .21 \\
\hline \multicolumn{8}{|c|}{ Fall data } \\
\hline 1-day rainfall ${ }^{1}$ & 617 & 61.6 & 1.55 & $<.0001$ & 1.18 & $<.0001$ & .11 \\
\hline 2-day rainfall ${ }^{2}$ & 617 & 58.9 & 1.13 & $<.0001$ & 1.11 & $<.0001$ & .19 \\
\hline 3-day rainfall ${ }^{3}$ & 617 & 60.1 & .860 & $<.0001$ & 1.10 & $<.0001$ & .16 \\
\hline 4-day rainfall ${ }^{4}$ & 617 & 58.5 & .740 & $<.0001$ & 1.05 & $<.0001$ & .20 \\
\hline Weighted rainfall ${ }^{5}$ & 617 & 56.4 & .508 & $<.0001$ & 1.03 & $<.0001$ & .21 \\
\hline
\end{tabular}

${ }^{1}$ Rainfall was the amount in inches that fell on the day of sampling before sample collection.

${ }^{2}$ Rainfall was the amount in inches that fell on the day of and 1 day before sampling.

${ }^{3}$ Rainfall was the amount in inches that fell on the day of and 2 days before sampling.

${ }^{4}$ Rainfall was the amount in inches that fell on the day of and 3 days before sampling.

${ }^{5}$ Weighted rainfall was the amount in inches that fell on the day of and 3 days before sampling, with the most recent rainfall receiving the highest weight. 
Multiple-linear regression extends simple-linear regression by adding additional variables. Variables are added to the model to explain more of the variation in the fecal-coliform data, and to leave as little variation as possible in the data (Helsel and Hirsch, 1992). Stepwise regression (Helsel and Hirsch, 1992) initially was used to identify factors or a combination of factors that are most useful in explaining the variation in the dependent variable (fecal-coliform concentrations). Stepwise regression evaluates variables according to their amount of significance in the model (Helsel and Hirsch, 1992). To reduce multicollinearity during stepwise procedures, only one rainfall variable was used in the procedure, so stepwise procedures were run multiple times to include all rainfall variables in combination with other environmental factors. For the multiple-linear regression analysis, equations were selected among all possible variable combinations to maximize the coefficient of determination $\left(\mathrm{R}^{2}\right)$ and minimize the standard errors.

Wind speed, wind direction, salinity, peak and average intensity of rainfall, 1-day rainfall, and 2-day rainfall were not statistically significant in explaining variation in fecal-coliform concentrations and were not included in the equations. Data that included percent sewer, percent septic, and population density within selected basins also were not statistically significant in explaining variation in fecal-coliform concentrations. Of all the rainfall variables, 2-day, 4-day, and weighted rainfall, in combination with water temperature and turbidity, had the highest $\mathrm{R}^{2}$ values and lowest standard error in the multiple regression models. Two-day (spring) and 4-day (fall) rainfall were chosen for representing the rainfall variable in the equations because it is measured easily.

The equation that explained most of the variation in the spring dataset $\left(R^{2}=0.48\right)$ and included 2-day rainfall, water temperature, and turbidity is

$$
\begin{aligned}
\log _{10} F C=.433 & +.897(\text { rainfall } 2)-0.822(\text { w_temp }) \\
& +1.556(\text { turb }) .
\end{aligned}
$$

The equation that explained most of the variation in the fall dataset $\left(R^{2}=0.43\right)$ and included 4-day rainfall, water temperature, and turbidity is $\log _{10} F C=0.600+1.022($ rainfall 4$)+0.675\left(w_{\text {_temp }}\right)$ -0.432 (turb),

where

$F C$ is the fecal-coliform concentration, in most probable number per $100 \mathrm{~mL}$;

rainfall2 is the total 2-day cumulative rainfall, in inches, before sample collection;

rainfall4 is the total 4-day cumulative rainfall, in inches, before sample collection;

w_temp is the $\log _{10}$ water temperature at each site at time of sample collection, in degrees Celsius; and

turb is the $\log _{10}$ turbidity at each site at time of sample collection, in Neophelometric Turbidity Units.

The $\mathrm{R}^{2}$ value indicates that $43-48$ percent of the variability in fecal-coliform concentrations, in the fall and spring, respectively, can be explained by a combination of the variables used in the equation. Rainfall, water temperature, and turbidity affected fecal-coliform concentrations in both seasons. Different rainfall variables, however, were significant for each season. The 2-day rainfall variable affected concentrations more in the spring, whereas the 4-day rainfall variable affected concentrations more in the fall. During the spring, direct surface runoff may have more of an immediate effect on water quality in the Harbor. There also may be more particulate matter during the spring as indicated with turbidity. In a similar study, Francy and Darner (1998) were able to account for 58 percent of the variability in Escherchia coli concentrations at public bathing beaches. The chosen regression model in that study contained a rainfall variable, beach-specific turbidity, and wave heights.

The natural variability in fecal coliforms may affect the ability to predict fecal-coliform concentrations based on environmental factors alone. Other factors that may improve some of the explanation of the variation in fecal-coliform concentrations in the equation, but were not available for this study, are fecal-coliform concentrations in wastewater effluent, active boat use, and quantitative data on bird populations. A more detailed sampling program of fecal coliforms from stormwater discharges also may define more variability in fecal-coliform concentrations. 


\section{SUMMARY}

Hampton/Seabrook Harbor (Harbor) and nearby tributaries constitute one of the most productive shellfish habitats in New Hampshire. The Harbor is in an estuary that is the most popular location in coastal New Hampshire for recreational harvesting of softshell clams. Closures for recreational clam harvesting because of concentrations of fecal coliform exceeding standards are common at the Harbor. These closures typically are implemented in response to rainfall and are based on the National Shellfish Sanitation Program (NSSP) water-quality standards for concentrations of fecal-coliform bacteria. This report describes the results of a study by the U.S. Geological Survey, in cooperation with the New Hampshire Department of Environmental Services, designed to determine the degree to which environmental factors affect fecal-coliform concentrations. Water samples and data on other environmental factors were collected on a monthly and rainfall-event basis throughout 2000 and 2001, with emphasis on the spring and fall. Water samples were analyzed for fecal-coliform concentrations. Data for other environmental factors collected included rainfall, salinity, turbidity, water temperature, wind speed, wind direction, air temperature, qualitative counts on bird populations, and basin characteristics such as area served by municipal sewer, on-site septic systems, and population density.

The collected data were used to characterize the temporal and spatial distributions of fecal-coliform concentrations in the Harbor by season. Statistical tests indicated that fecal-coliform concentrations are significantly different among some seasons, specifically between spring and fall $(\mathrm{p}<0.05)$. In general, samples collected during neap-tide cycles, had higher fecal-coliform concentrations than samples collected during spring-tide cycles. Median fecal-coliform concentrations increased with increased rainfall events indicating that rainfall affects fecal-coliform concentrations in the Harbor. Direct surface runoff may be contributing to the increase in fecal-coliform concentrations in the Harbor during and after periods of rainfall events.

Correlation analysis was used to measure the strength of the relations between fecal-coliform concentrations and other factors. The strongest correlations were found between fecal-coliform concentrations and rainfall variables $(\mathrm{p}<0.05$; rho $=$ $0.27-0.59$ ). There were statistically significant correlations between fecal-coliform concentrations and turbidity for the spring samples $(\mathrm{p}<0.05$; rho $=$ 0.45 ) but not for other seasons. Statistical correlations between fecal-coliform concentrations and other environmental factors were weak or not statistically significant.

Simple-linear-regression analysis was used to determine if rainfall and other factors such as salinity and turbidity could explain some of the variability in fecal-coliform concentrations. Total 4-day and weighted rainfall provided the highest $\mathrm{R}^{2}$ values when compared to peak and average intensity, 1-day, and 2-day rainfall. The $\mathrm{R}^{2}$ values for the regression between fecal-coliform concentrations and 4-day and weighted rainfall were low $\left(\mathrm{R}^{2}=0.18-0.21\right)$, which indicated there are other possible factors affecting fecal-coliform concentrations.

Multiple-linear-regression analysis was used to include a combination of factors that may explain more of the variability than simple-linear-regression models. Two-day (spring) and 4-day (fall) rainfall, water temperature, and turbidity improved the regression $\left(R^{2}=0.43-0.48\right)$. The additional variables increased the explanation of variance found when only rainfall was used. Because rainfall is an important factor in explaining the variability in fecal-coliform concentrations, a more detailed study of stormwater inflows may further refine the conditions under which fecal-coliform concentrations increase.

\section{REFERENCES CITED}

Aldom, J., Jamieson, E., Prout, T., Walsh, M., Van Bakel, D., Griffiths, R., and Palmateer, G., 1998, Rapid fecal coliform and Escherichia coli detection in the recreational waters of Lake Huron beaches and an inland beach 1997: London Ontario, Ausable Bayfield Conservation Authority, $32 \mathrm{p}$.

American Public Health Association, American Water Works Association, and Water Pollution Control Federation, 1995, Standard methods for the analysis of water and wastewater ( $19^{\text {th }}$ ed.): Washington, D.C., American Public Health Association Section 9222D and 9221E [variously paged].

Chapman, A.T., and Nash, W.C., 2002, Quality assurance project plan for shellfish water quality monitoring, New Hampshire Shellfish Sanitation Program, Concord, N.H.: New Hampshire Department of Environmental Services [variously paged]. 
Francy, D.S., and Darner, R.A., 1998, Factors affecting Escherichia coli concentrations at Lake Erie public bathing beaches: U.S. Geological Survey WaterResources Investigations Report 98-4241, 41 p.

Frenzel, S.A., and Couvillion, C.S., 2002, Fecal-indicator bacteria in streams along a gradient of residential development: Journal of the American Water Resources Association, v. 38, no. 1, p. 265-273.

Geolytics, Inc., 1998, Census CD and maps, Release 2.1: East Brunswick, N.J.

Grimes, D.J., 1980, Bacteriological water quality effects of hydraulically dredging contaminated upper Mississippi River bottom sediment: Applied and Environmental Microbiology, v. 34, no. 2, p. 139-149.

Helsel, D.R., and Hirsch, R.M., 1992, Statistical methods in water resources: New York, Elsevier Science Publishers, $522 \mathrm{p}$.

Jones, S.H., 2001, A technical characterization of estuarine and coastal New Hampshire: New Hampshire Estuaries Project Report [variously paged].

Lehman, G.S., and Fogel, M.M., 1976, Investigation of bacteriological pollution of recreational water in Arizona: Tucson, Ariz., University of Arizona Department of Watershed Management and University of Arizona School of Renewable Natural Resources [variously paged].

Mathsoft, Inc., 1999, S-Plus 2000 Guide to statistics, v. 1: Seattle, Wash., Data Analysis Products Division, $638 \mathrm{p}$.

Meyers, D.N., and Sylvester, F.D., 1997, National field manual for the collection of water-quality data-Biological indicators: U.S. Geological Survey Techniques of Water-Resources Investigations, book A9, chap. A7, 38 p.

Nash, W.C., 1999, Analysis of historical bacteriological data for Hampton/Seabrook Harbor, 1991-1998: New Hampshire Department of Environmental Services, $23 \mathrm{p}$.

2002, New Hampshire Department of Environmental Services Shellfish Program 2001 Annual Report: New Hampshire Department of Environmental Services Report no. R-WD-02-3, 48 p.
Nash, W.C., and Chapman, A.T., 2001, New Hampshire Department of Environmental Services Shellfish Program 2000 Annual Report: New Hampshire Department of Environmental Services Report no. R-WD-01-8, 46 p.

New Hampshire Division of Public Health Services, 1994, Sanitary survey report for Hampton Harbor: Concord, N.H., 38 p., plus appendix.

Painchaud, L., Lefaivre, D., Therriault, J.C., and Legendre, L., 1995, Physical processes controlling bacterial distribution and variability in the Upper St. Lawrence Estuary: Estuaries, v. 18, no. 3, p. 433-444.

Puddu, A., LaFerla, R., Allegra, A., Bacci, C., Lopez, M., Olivia, F., and Pierotti, C., 1998, Seasonal and spatial distribution of bacterial production and biomass along a salinity gradient (Northern Adriatic Sea): Hydrobiologia, v. 363, p. 271-282.

Roper, M.M., and Marshall, K.C., 1979, Effects of salinity on sedimentation and of particulates on survival of bacteria in estuarine habitats: Geomicrobiology Journal, v. 1, no. 2, p. 103-116.

Rubin, F., and Merriam, J., 1998, Critical lands analysis: A final report to the New Hampshire Estuaries Project: no. NHEP \#RES-8, 20 p.

SAS Institute, Inc., 1998, Statview reference guide, version 5.0: Cary, N.C., 528 p.

Struck, P.H., 1988, The relationship between sediment and fecal coliform levels in a Puget Sound Estuary: Journal of Environmental Health, v. 50, no. 7, p. 403407.

Tunnicliff, B., and Brickler, S., 1984, Recreational water quality analyses of the Colorado River corridor in the Grand Canyon: Applied and Environmental Microbiology, v. 48, no. 5, p. 909-917. 


\section{JSGS Deacon and Nash-ASSESSMENT OF ENVIRONMENTAL FACTORS AFFECTING FECAL-COLIFORM CONCENTRATIONS IN HAMPTON/SEABROOK

sclence for a clanenging worted 